\title{
Coconut Coir Synergism with Plant Residues augments the Potting Media Quality and Lettuce Growth
}

\author{
Afshan*, Shahzada Sohail Ijaz, Ghulam Jilani and Ayaz Ahmad \\ Institute of Soil Science, PMAS Arid Agriculture University Rawalpindi, Pakistan \\ *Corresponding Author: Afshan, Institute of Soil Science, PMAS Arid Agriculture University Rawalpindi, Pakistan.
}

Received: October 18, 2019; Published: October 31, 2019

DOI: 10.31080/ASAG.2019.03.0709

\begin{abstract}
Commercial potting mixes often contain coconut coir as an alternative of peat. With the aim to find an economical and efficient potting medium, some plant residues, viz., coconut coir (CNC), date palm coir (DPC), rice hulls (RH), saw-dust (SD) and corn cobs (CC) alone as well as combined with CNC (1:1), were evaluated for the growth and nutrient accumulation of lettuce. Morphological plant parameters indicated that $\mathrm{CNC}+\mathrm{RH}$ and $\mathrm{CNC}+\mathrm{CC}$ performed better than all the sole and other combined potting media. Potting mix containing $\mathrm{CNC}$ had higher nitrogen content and rendered greater leaf area index of lettuce plants. Regarding chemical parameters, $\mathrm{pH}$ of all potting mixes was almost neutral; $\mathrm{CNC}+\mathrm{RH}$ potting mix rendered the highest nutrient contents in lettuce leaves if compared with rest of the substrates. These results reflect that largely available and cheaper plant residues could be exploited to prepare alternative potting media in combination with expensive coconut coir substrate.
\end{abstract}

Keywords: Agricultural Wastes; Integrate; Local Potting Substrates; Nutrients; Rice Hulls; Corn Cobs

\section{Introduction}

In soilless culture, plants are grown without the usage of soil [1]. Due to higher yields from small areas, soilless production can be more cost-effective as compared to soil-based farming [2,3]. Similarly, water and nutrient use efficiencies are higher in soilless methods [1]. Consequently, these media are becoming popular over the last few decades [4]. Media suitable for growing container plants are composed of mixtures that are warm enough to facilitate seed germination, hold sufficient moisture, drain excessive water and provide required nutrients for plant growth and development [5]. Currently, an extensive range of growth media based on natural and artificial materials are being introduced for flower and vegetable production [6,7].

Organic materials such as sphagnum peat moss have extensively been used as main ingredient in soilless potting mixes in combination with inorganic materials such as perlite, vermiculite and fertilizers [8]. Globally, $11 \mathrm{~m}$ t of peat is consumed for horticultural purposes annually [9]. However, there has been increasing environmental and ecological concerns against the use of peat because its harvest is destroying endangered wetland ecosystems worldwide (Barkham 1993). Coconut coir is being successful used as an environmentally sound peat substitute for ornamental plants (Handreck 1993; Noguera., et al. 2000). Nevertheless, coconut is not grown in all parts of the world. Several other organic materials like rice hulls, saw dust, corn cobs and date palm coir are widely available as cheaper substrates. They are not biodegradable in short term and hence do not create disposal problems in the environment. Processing of these materials into a usable form is an employment generation activity in rural areas. Therefore, it is hypothesized that locally available materials could be successfully used as substitute to coconut coir for container-grown plants. Specific objective of this research was to find out the alternative of coconut coir from local plant materials for potting mix.

\section{Materials and Methods}

Greenhouse experiment in plastic pots was conducted with nine potting mix treatments and three replications arranged according to completely randomized design (CRD). Basic composition of potting mixes used was: $0.75 \mathrm{~L}$ coconut coir (CNC), $0.75 \mathrm{~L}$ compost, $1.5 \mathrm{~L}$ vermiculite, $3.6 \mathrm{~g}$ single super phosphate (SSP) fertilizer, 1.8 g calcium ammonium nitrate (CAN) fertilizer, $9 \mathrm{~g}$ dolomitic limestone, $0.33 \mathrm{~g}$ wetting agent and $0.22 \mathrm{~g}$ trace elements. Nine potting media as treatments were prepared by replacing or including the coconut coir substrate. These were: coconut coir (CNC), date palm coir (DPC), rice hulls (RH), saw dust (SD), corn cobs (CC), CNC+DPC (1:1), CNC+RH (1:1), CNC+SD (1:1) and CNC+CC) (1:1).

Lettuce seeds were grown in trays, and after emergence, seedlings were transplanted in pots containing aforementioned potting mixes. Samples of individual plant materials, potting mixes and lettuce plants were collected in separate paper bags. Samples were dried in the oven overnight at $65^{\circ} \mathrm{C}$. Dried samples were grinded by the plant grinder. Ground samples were transferred to tightly capped glass jars, and stored for further analyses.

For the analyses of potting mix as well as plant samples, $\mathrm{pH}$ and EC were measured according to the procedures described by Jackson [10], while total nitrogen was determined by the Kjeldahl's method [11]. Phosphorus and potassium analyses were performed 
by ammonium vanadate molybdate method [12] and flame photometry, respectively [13]. Manganese, zinc and copper were determined on atomic absorption spectrophotometer using relevant lamp for each element [14].

Plant growth parameters were measured as per standard procedures like shoot length by metric scale, leaves per plant by manual counting, leaf area index by graph paper method, fresh and dry weight of plant shoots and roots by weighing on the electrical balance.

Data collected for various parameters were subjected to analysis of variance (ANOVA) and the means were compared at $5 \%$ level of significance using Tukey's HSD test [15]. Statistics 8.1 software was used for statistical analysis of data.

\section{Results and Discussion}

\section{Characteristics of potting mix}

Data on chemical analysis of potting mixes as treatments are shown in table 1. Various potting media exhibited minor differences in their $\mathrm{pH}$ value. The highest value of $\mathrm{pH}$ (7.45) was recorded in CNC+DPC followed by DPC, SD, and CNC+CC with 7.43, 7.39 and $7.39 \mathrm{pH}$ values, respectively. The lowest $\mathrm{pH}$ value (7.19) was that of CNC. The results regarding electrical conductivity showed the highest value of EC $\left(1.97 \mathrm{dS} \mathrm{m}^{-1}\right)$ recorded in CNC followed by $\mathrm{CNC}+\mathrm{SD}\left(1.74 \mathrm{dS} \mathrm{m}^{-1}\right), \mathrm{CNC}+\mathrm{RH}\left(1.59 \mathrm{dS} \mathrm{m}^{-1}\right)$ and CNC+CC $(1.53 \mathrm{dS}$ $\left.\mathrm{m}^{-1}\right)$, but all with non-significant difference. The lowest value of EC was recorded in CNC+DPC $\left(1.07 \mathrm{dS} \mathrm{m}^{-1}\right)$.

\begin{tabular}{|c|c|c|c|c|c|c|c|c|}
\hline Treatments* & pH & $E C\left(d S ~ m^{-1}\right)$ & N (\%) & P (\%) & K (\%) & Mn (mg kg-1) & $\mathrm{Zn}\left(\mathrm{mg} \mathrm{kg}^{-1}\right)$ & $\mathrm{Cu}\left(\mathrm{mg} \mathrm{kg}^{-1}\right)$ \\
\hline $\mathrm{CNC}$ & $7.19 \mathrm{C}$ & $1.97 \mathrm{~A}$ & $0.79 \mathrm{~A}$ & $0.06 \mathrm{~A}$ & $1.76 \mathrm{~A}$ & $8.9 \mathrm{~A}$ & $2.16 \mathrm{~B}$ & $1.36 \mathrm{~A}$ \\
\hline DPC & $7.43 \mathrm{AB}$ & $1.23 \mathrm{BC}$ & $0.44 \mathrm{~B}$ & $0.13 \mathrm{~A}$ & $2.04 \mathrm{~A}$ & $8.25 \mathrm{AB}$ & $2.47 \mathrm{AB}$ & $1.26 \mathrm{~A}$ \\
\hline RH & 7.28 ABC & $1.24 \mathrm{BC}$ & $0.38 \mathrm{~B}$ & $0.14 \mathrm{~A}$ & $2.18 \mathrm{~A}$ & $8.38 \mathrm{AB}$ & $2.46 \mathrm{AB}$ & $1.46 \mathrm{~A}$ \\
\hline SD & $7.39 \mathrm{AB}$ & $1.35 \mathrm{ABC}$ & $0.34 \mathrm{~B}$ & $0.15 \mathrm{~A}$ & $1.68 \mathrm{~A}$ & $8.92 \mathrm{~A}$ & $2.42 \mathrm{AB}$ & $2.6 \mathrm{~A}$ \\
\hline $\mathrm{CC}$ & $7.35 \mathrm{ABC}$ & $1.19 \mathrm{BC}$ & $0.47 \mathrm{AB}$ & $0.16 \mathrm{~A}$ & $2.37 \mathrm{~A}$ & $8.59 \mathrm{AB}$ & $2.71 \mathrm{~A}$ & $1.32 \mathrm{~A}$ \\
\hline $\mathrm{CNC}+\mathrm{DPC}$ & $7.45 \mathrm{~A}$ & $1.072 \mathrm{C}$ & $0.38 \mathrm{~B}$ & $0.24 \mathrm{~A}$ & $1.85 \mathrm{~A}$ & $8.13 \mathrm{AB}$ & $2.35 \mathrm{AB}$ & $1.7 \mathrm{~A}$ \\
\hline $\mathrm{CNC}+\mathrm{RH}$ & $7.33 \mathrm{ABC}$ & $1.59 \mathrm{ABC}$ & $0.29 \mathrm{~B}$ & $0.27 \mathrm{~A}$ & $3.05 \mathrm{~A}$ & $9.04 \mathrm{~A}$ & $2.71 \mathrm{~A}$ & $3.26 \mathrm{~A}$ \\
\hline $\mathrm{CNC}+\mathrm{SD}$ & $7.26 \mathrm{BC}$ & $1.73 \mathrm{AB}$ & $0.23 \mathrm{~B}$ & $0.31 \mathrm{~A}$ & $1.24 \mathrm{~A}$ & $7.34 \mathrm{BC}$ & $2.36 \mathrm{AB}$ & $0.4 \mathrm{~A}$ \\
\hline $\mathrm{CNC}+\mathrm{CC}$ & $7.39 \mathrm{AB}$ & $1.53 \mathrm{ABC}$ & $0.33 \mathrm{~B}$ & $0.17 \mathrm{~A}$ & $2.11 \mathrm{~A}$ & $6.65 \mathrm{C}$ & $2.24 \mathrm{AB}$ & $0.26 \mathrm{~A}$ \\
\hline
\end{tabular}

Table 1: Chemical characteristics of potting mixes before lettuce plantation ${ }^{*}$ CNC (coconut coir), DPC (date palm), RH (rice hulls), SD (saw dust) and CC (corn cobs).

Recipe: $0.75 \mathrm{~L}$ substrate $+0.75 \mathrm{~L}$ compost $+1.5 \mathrm{~L}$ vermiculite $+3.6 \mathrm{~g} \mathrm{SSP}+1.8 \mathrm{~g}$ CAN $+9 \mathrm{~g}$ dolomitic imestone + $0.33 \mathrm{~g}$ wetting agent $+0.22 \mathrm{~g}$ trace elements.

Contents of total nitrogen showed superiority of CNC over other treatments, having $0.79 \%$ nitrogen followed by CC with $0.47 \% \mathrm{~N}$. The lowest nitrogen content $(0.23 \%)$ was found in CNC+SD. Other treatments had nitrogen concentration with values ranging from $0.47 \%$ to $0.23 \%$. Statistically, phosphorus contents did not differ among all the treatments. However, maximum phosphorus was recorded in $\mathrm{CNC}+\mathrm{SD}(0.31 \%)$ followed by $\mathrm{CNC}+\mathrm{RH}$ and $\mathrm{CNC}+\mathrm{DPC}$ with $0.27 \%$ and $0.24 \%$. The lowest value of phosphorus content was recorded in $\mathrm{CNC}(0.06 \%)$. Comparison of different growing media revealed that $\mathrm{CNC}+\mathrm{RH}$ had the highest potassium content (3.05\%) as compared to rest of the substrates. However, all of the treatments did not differ significantly on the basis of $\mathrm{K}$ contents.

Comparison of different potting media revealed that most of them had similar manganese $(\mathrm{Mn})$ content except $\mathrm{CNC}+\mathrm{CC}$, which showed significantly lower Mn content. The $\mathrm{CNC}+\mathrm{RH}$ had the highest Mn content ( $9.05 \mathrm{mg} \mathrm{kg}^{-1}$ ) as compared to rest of the substrates. While, the lowest Mn contents of potting media comprising $\mathrm{CNC}+\mathrm{CC}$ and $\mathrm{CNC}+\mathrm{SD}$ were 6.65 and $7.34 \mathrm{mg} \mathrm{kg}^{-1}$, respectively. Comparison of different potting media for zinc content revealed that there were minor differences in zinc content among them. The $\mathrm{CNC}+\mathrm{RH}$ had the highest zinc content $\left(2.72 \mathrm{mg} \mathrm{kg}^{-1}\right)$ followed by CC having zinc content $2.71 \mathrm{mg} \mathrm{kg}^{-1}$. The lowest zinc content was $2.16 \mathrm{mg} \mathrm{kg}-1$ in the potting media comprising of CNC alone. Comparison of different potting media revealed that all the potting mixes had statistically equal $\mathrm{Cu}$ content. Numerically, $\mathrm{CNC}+\mathrm{RH}$ had the highest copper content $\left(3.26 \mathrm{mg} \mathrm{kg}^{-1}\right)$ of potting media followed by SD with 2.61 $\mathrm{mg} \mathrm{kg}^{-1}$ zinc content. The CNC+DPC, RH, CNC, CC and DP contained $1.70,1.46,1.36,1.32$ and $1.26 \mathrm{mg} \mathrm{Cu} \mathrm{kg}^{-1}$, respectively. While, the lowest zinc contents of potting media were in $\mathrm{CNC}+\mathrm{SD}$ and $\mathrm{CNC}+\mathrm{CC}$ being 0.40 and $0.26 \mathrm{mg} \mathrm{kg}^{-1}$, respectively. However, there was statistically non-significant difference in copper content among all the potting media.

\section{Growth attributes of lettuce}

Data on several plant growth attributes of lettuce harvested after 45 days of seedlings transplantation were recorded (Table 2). There was statistically non-significant difference among most of the treatments regarding number of leaves except that of DPC Producing 13leaves followed by $\mathrm{CNC}+\mathrm{RH}(9)$ and $\mathrm{CNC}$ control treatment (8). 


\begin{tabular}{|c|c|c|c|c|c|c|c|}
\hline Treatments* & $\begin{array}{l}\text { Leaf count } \\
\left(\# \text { plant }^{-1}\right)\end{array}$ & $\begin{array}{c}\text { Plant } \\
\text { height }(\mathrm{cm})\end{array}$ & $\begin{array}{c}\text { Leaf area } \\
\left(\mathrm{cm}^{2}\right)\end{array}$ & 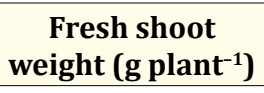 & 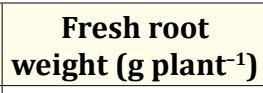 & 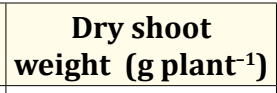 & $\begin{array}{c}\text { Dry root } \\
\text { weight }\left(\mathrm{g} \text { plant }^{-1}\right) \\
\end{array}$ \\
\hline $\mathrm{CNC}$ & $8.33 \mathrm{AB}$ & $12.59 \mathrm{~A}$ & $6.5 \mathrm{~A}$ & $8.5 \mathrm{CD}$ & $4.95 \mathrm{ABC}$ & $1.33 \mathrm{AB}$ & $1.28 \mathrm{C}$ \\
\hline DPC & $13.44 \mathrm{~A}$ & $12.23 \mathrm{AB}$ & $5.6 \mathrm{~A}$ & $4.77 \mathrm{CD}$ & $5.59 \mathrm{CDE}$ & $0.8 \mathrm{BC}$ & $0.87 \mathrm{C}$ \\
\hline $\mathrm{RH}$ & $7.33 \mathrm{~B}$ & $11.68 \mathrm{~A}$ & $4.58 \mathrm{~A}$ & $6.4 \mathrm{CD}$ & $5.39 \mathrm{BCD}$ & $1.07 \mathrm{BC}$ & $1.87 \mathrm{BC}$ \\
\hline SD & $5.89 \mathrm{~B}$ & $6.83 \mathrm{CD}$ & $1.3 \mathrm{~B}$ & $0.6 \mathrm{D}$ & $0.46 \mathrm{E}$ & $0.11 \mathrm{D}$ & $0.087 \mathrm{C}$ \\
\hline $\mathrm{CC}$ & $6.67 \mathrm{~B}$ & $3.56 \mathrm{D}$ & $1.28 \mathrm{~B}$ & $0.52 \mathrm{D}$ & $0.57 \mathrm{E}$ & $0.06 \mathrm{D}$ & $0.17 \mathrm{C}$ \\
\hline $\mathrm{CNC}+\mathrm{DPC}$ & $6.67 \mathrm{~B}$ & $9.42 \mathrm{BC}$ & $2.5 \mathrm{~B}$ & $3.55 \mathrm{CD}$ & $4.97 \mathrm{DE}$ & $0.54 \mathrm{CD}$ & $1.13 \mathrm{C}$ \\
\hline $\mathrm{CNC}+\mathrm{RH}$ & $9 \mathrm{AB}$ & $12.24 \mathrm{~A}$ & $5.41 \mathrm{~A}$ & $11.83 \mathrm{~A}$ & $14.97 \mathrm{~A}$ & $1.73 \mathrm{~A}$ & $4.2 \mathrm{~A}$ \\
\hline $\mathrm{CNC}+\mathrm{SD}$ & $7.67 \mathrm{AB}$ & $9.81 \mathrm{AB}$ & $5.5 \mathrm{~A}$ & $7.27 \mathrm{BC}$ & $7.95 \mathrm{BCD}$ & $1.04 \mathrm{BC}$ & $1.97 \mathrm{BC}$ \\
\hline $\mathrm{CNC}+\mathrm{CC}$ & $7.22 \mathrm{~B}$ & $9.86 \mathrm{~A}$ & $5.3 \mathrm{~A}$ & $10.67 \mathrm{AB}$ & $13.5 \mathrm{AB}$ & $1.32 \mathrm{AB}$ & $3.7 \mathrm{AB}$ \\
\hline
\end{tabular}

Table 2: Plant growth parameters as influenced by different potting mixes.

*CNC (coconut coir), DPC (date palm), RH (rice hulls), SD (saw dust) and CC (corn cobs).

Recipe: $0.75 \mathrm{~L}$ substrate $+0.75 \mathrm{~L}$ compost $+1.5 \mathrm{~L}$ vermiculite $+3.6 \mathrm{~g} \mathrm{SSP}+1.8 \mathrm{~g}$ CAN +9 g dolomitic limestone $+0.33 \mathrm{~g}$ wetting agent $+0.22 \mathrm{~g}$ trace elements.

The CNC, DPC, RH and CNC+RH substrates resulted in greater plant height of $12.59,12.23,11.68$ and $12.23 \mathrm{~cm}$; also these treatments had statistically non-significant difference. Plant height with $\mathrm{CNC}+\mathrm{CC}$ was $9.86 \mathrm{~cm}$ followed by CNC+SD and CNC+DPC with 9.81 and $9.42 \mathrm{~cm}$, respectively. Performance of SD and CC was not satisfactory as they resulted in the smallest plant height of 6.83 and $3.56 \mathrm{~cm}$, respectively. Results indicated that the DPC, $\mathrm{CNC}+\mathrm{RH}$ and $\mathrm{RH}$ exerted significant effect on plant height as compared to other substrates.

There was statistically no difference among various treatments except SD, CC and CNC+DPC for leaf area. Maximum leaf area (6.5 $\mathrm{cm}^{2}$ ) was recorded under $\mathrm{CNC}$, while minimum $(1.28 \mathrm{~cm} 2)$ in $\mathrm{CC}$ substrate. Similarly, CNC+DPC, SD and CC also had statistically non-significant difference with leaf area of $2.5,1.3$ and $1.28 \mathrm{~cm} 2$, respectively.

Comparison of all substrate treatments showed that statistically significance difference was present. The $\mathrm{CNC}+\mathrm{RH}$ produced the highest fresh shoot weight per plant (11.83 g) followed by CNC+CC and CNC+SD with 10.67 and $7.29 \mathrm{~g}$, respectively. These treatments produced significantly higher fresh shoot weight as compared to control treatment with CNC.

There was statistically significant difference among all the treatments. Each treatment produced different fresh root weight. The CNC+RH produced the highest fresh root weight $14.97 \mathrm{~g}$ per plant followed by CNC+CC (13.5 g) and CNC+SD (7.95 g). While, the lowest fresh root weight was recorded in SD $(0.46 \mathrm{~g})$.

Comparison of all treatments showed statistically significant difference as $\mathrm{CNC}+\mathrm{RH}$ produced maximum oven dry plant shoot weight $(1.74 \mathrm{~g})$ followed by $\mathrm{CNC}+\mathrm{CC}$ and $\mathrm{CNC}$ with 1.32 and 1.3 g per plant, respectively. The CNC+DPC, SD and CC rendered the lowest $0.54,0.11$ and $0.06 \mathrm{~g}$ dry plant shoot weight, respectively.

Each treatment produced different dry root weight. The $\mathrm{CNC}+\mathrm{RH}$ had the highest dry root weight of $4.20 \mathrm{~g}$ followed by $\mathrm{CNC}+\mathrm{CC}(3.71 \mathrm{~g}), \mathrm{CNC}+\mathrm{SD}(1.95 \mathrm{~g}), \mathrm{RH}(1.87 \mathrm{~g})$ and CNC (1.28 g). While, all other treatments, viz., CNC+DPC, DPC, CC, and SD had sta- tistically non-significant difference with $1.13,0.87,0.11$, and $0.08 \mathrm{~g}$ dry root weight, respectively.

\section{Composition of lettuce plant}

There was statistically no significant difference in total nitrogen of all treatments plants except SD and C Cb. Nitrogen content of plant growing in potting media containing $\mathrm{CC}+\mathrm{RH}$ was the highest $(0.4109 \%)$ followed by CNC+CC $0.3455 \%$, CC+SD $0.3455 \%$, CNC+DPC $0.3362 \%$, CC $0.3268 \%$, RH $0.3082 \%$, and DP $0.2708 \%$ while the lowest nitrogen content of $0.2241 \%$ and $0.3082 \%$ was in plants of potting media containing SD and C Cb respectively. Plants of all potting media had almost same nitrogen content. There is almost non-significant difference among all potting media. Potting media containing $\mathrm{CC}$ had maximum nitrogen content but plants of $\mathrm{CC}+\mathrm{RH}$ had highest nitrogen content. It may be due to more availability of nutrients to plants. There was statistically no difference in all treatments for phosphorus content. CNC+DPC produced the plants with highest nitrogen content $(1.8586 \mathrm{mg} \mathrm{kg}-1)$ while the lowest phosphorus content of $0.08 \%$ was in plants of potting media containing SD. Plants growing in CNC media were statistically different in Potassium content from that of CC and CNC+RH. However, all other difference was non-significant while being highest $(2.85 \%)$ in potting media containing CC. The lowest potassium content of $(0.79 \%)$ was in plants of potting media containing $\mathrm{CC}+\mathrm{RH}$.

Plants of potting media containing $\mathrm{CNC}+\mathrm{CC}$ had the highest manganese content $\left(3.9716 \mathrm{mg} \mathrm{kg}^{-1}\right)$, while the lowest manganese content of $\left(1.2636 \mathrm{mg} \mathrm{kg}^{-1}\right)$ was produced by plants of potting media containing SD. Zinc content of plants had statistically lesser difference in all treatments. Zinc content of plant growing in potting media containing $\mathrm{CNC}+\mathrm{CC}$ was the highest $(1.9834 \mathrm{mg}$ $\mathrm{kg}^{-1}$ ) followed by CNC+DPC $1.7561 \mathrm{mg} \mathrm{kg}^{-1}$, while the lowest zinc content of $\left(0.8314 \mathrm{mg} \mathrm{kg}^{-1}\right)$ was in plants of potting media containing CC+RH. There was statistically minimum difference for copper content among all treatments. Copper content of plant growing in potting media containing CNC+DPC was the highest $(0.271 \mathrm{mg} \mathrm{kg}-$ $\left.{ }^{1}\right)$, closely followed by RH $\left(0.2638 \mathrm{mg} \mathrm{kg}^{-1}\right)$, while the lowest copper content of $0.0629 \mathrm{mg} \mathrm{kg}^{-1}$ was in plants of potting media containing $\mathrm{CC}+\mathrm{SD}$. CC had less copper content $\left(0.2043 \mathrm{mg} \mathrm{kg}^{-1}\right)$ than RH and CNC+DPC. Composition of lettuce plant was shown in table 3. 


\begin{tabular}{|c|c|c|c|c|c|c|}
\hline Treatments & N (\%) & $P(\%)$ & K (\%) & Mn (mg kg-1) & $\mathrm{Zn}\left(\mathrm{mg} \mathrm{kg}^{-1}\right)$ & $\mathrm{Cu}\left(\mathrm{mg} \mathrm{kg}^{-1}\right)$ \\
\hline $\mathrm{CNC}$ & $0.33 \mathrm{~A}$ & $0.17 \mathrm{~A}$ & $2.85 \mathrm{~A}$ & $1.97 \mathrm{~B}$ & $1.22 \mathrm{ABC}$ & $0.21 \mathrm{AB}$ \\
\hline DPC & $0.27 \mathrm{~A}$ & $0.18 \mathrm{~A}$ & $2.60 \mathrm{AB}$ & $1.28 \mathrm{~B}$ & $1.37 \mathrm{ABC}$ & $0.14 \mathrm{AB}$ \\
\hline RH & $0.31 \mathrm{~A}$ & $0.18 \mathrm{~A}$ & $2.45 \mathrm{AB}$ & $2.33 \mathrm{AB}$ & $1.33 \mathrm{ABC}$ & $0.26 \mathrm{~A}$ \\
\hline SD & $0.23 \mathrm{~B}$ & $0.08 \mathrm{~A}$ & $1.21 \mathrm{AB}$ & $1.26 \mathrm{~B}$ & $1.05 \mathrm{BC}$ & $0.13 \mathrm{AB}$ \\
\hline $\mathrm{CC}$ & $0.31 \mathrm{~B}$ & $0.14 \mathrm{~A}$ & $0.81 \mathrm{~B}$ & $1.66 \mathrm{~B}$ & $1 \mathrm{BC}$ & $0.13 \mathrm{AB}$ \\
\hline $\mathrm{CNC}+\mathrm{DPC}$ & $0.34 \mathrm{~A}$ & $0.18 \mathrm{~A}$ & $1.78 \mathrm{AB}$ & $2.8 \mathrm{AB}$ & $1.75 \mathrm{AB}$ & $0.27 \mathrm{~A}$ \\
\hline $\mathrm{CNC}+\mathrm{RH}$ & $0.41 \mathrm{~A}$ & $0.16 \mathrm{~A}$ & $0.79 \mathrm{~B}$ & $1.73 \mathrm{~B}$ & $0.83 \mathrm{C}$ & $0.14 \mathrm{AB}$ \\
\hline $\mathrm{CNC}+\mathrm{SD}$ & $0.35 \mathrm{~A}$ & $0.16 \mathrm{~A}$ & $1.42 \mathrm{AB}$ & $2.07 \mathrm{AB}$ & $1.38 \mathrm{ABC}$ & $0.06 \mathrm{~A}$ \\
\hline $\mathrm{CNC}+\mathrm{CC}$ & $0.35 \mathrm{~A}$ & $0.17 \mathrm{~A}$ & $2.06 \mathrm{AB}$ & $3.97 \mathrm{~A}$ & $1.98 \mathrm{~A}$ & $0.16 \mathrm{AB}$ \\
\hline
\end{tabular}

Table 3: Chemical composition of Lettuce in different potting mixes.

${ }^{*} \mathrm{CNC}$ (coconut coir), DPC (date palm), RH (rice hulls), SD (saw dust) and CC (corn cobs).

Recipe: $0.75 \mathrm{~L}$ substrate + $0.75 \mathrm{~L}$ compost $+1.5 \mathrm{~L}$ vermiculite + $3.6 \mathrm{~g} \mathrm{SSP}+1.8 \mathrm{~g}$ CAN + 9 g dolomitic limestone + $0.33 \mathrm{~g}$ wetting agent $+0.22 \mathrm{~g}$ trace elements.

\section{Discussion}

According to Bunt [16] average $\mathrm{pH}$ of coconut coir potting media ranges from 5.2 to 6.3 for growing ornamental plants. If $\mathrm{pH}$ is too acidic $(<4)$, micronutrients are abundantly available to plants, even up to toxicity level. If it is alkaline ( $>9)$, micronutrients mobility as well as uptake is reduced [17]. As the pH values of the potting media used in this study were within the normal range of 7.197.45 , so there was no adverse effect on plant growth. According to Bernstein (1975) high electrical conductivity $\left(>3.5 \mathrm{dS} \mathrm{m}^{-1}\right)$ exerts adverse effects on seed germination and growth of ornamental plants. Whereas, low EC level (0.24 and $\left.0.29 \mathrm{mS} \mathrm{cm}^{-1}\right)$ leads to plant nutrient deficiency [18]. The EC values recorded for all our potting media fall within optimal range of 1.19-1.97, so it was favorable characteristic for plant growth.

Nitrogen is one of the most important elements required for plant growth and reproduction. It is important part of chlorophyll, DNA and RNA and is also needed in periods of rapid plant growth. Nitrogen content in coconut coir reported by Magat., et al. [19] was $0.373 \%$. Most of potting media have similar nitrogen content because of application of equal amount of $\mathrm{N}$ fertilizer. It could also be assumed that all the local materials used have small difference in $\mathrm{N}$ content.

Acceptable phosphorus value for potting media ranges 3-5 mg $\mathrm{kg}^{-1}$ Ingram [20]. However, among our soilless potting media only $\mathrm{CNC}+\mathrm{SD}$ was within the mentioned range, while rest of the treatments had lower $\mathrm{P}$ contents. The acceptable potassium value for potting media is $60-149 \mathrm{mg} \mathrm{kg}^{-1}$, which shows that all mentioned treatments did not have acceptable $\mathrm{K}$ content for plant growth. All potting media had lower potassium content than acceptable range. Reason is that potassium contents present in our local materials were very low. Acceptable manganese value for potting media is $5-10 \mathrm{mg} \mathrm{kg}^{-1}$. By comparing this range, all potting media had acceptable manganese content for plant growth. The acceptable range for zinc of potting media is $5-10 \mathrm{mg} \mathrm{kg}^{-1}$. Range in our was $<5 \mathrm{mg} \mathrm{Mn} \mathrm{kg}^{-1}$ which shows that all treatments had lower zinc content than acceptable range, even less than the range of zinc content for plant growth. It means that used local materials did not have adequate zinc content and there is need to add $\mathrm{Zn}$ in these mixes. The optimal range for copper in potting media is $1.1-1.5 \mathrm{mg} \mathrm{kg}^{-1}$. It indicated that our potting media had acceptable copper content except in the potting media containing SD.

Date palm media produced the highest number of leaves at 7.43 $\mathrm{pH}$ as it had great effect on nutrient availability to plants. Two extremes were compared to $\mathrm{CNC}$ which had low $\mathrm{pH}, \mathrm{P}, \mathrm{K}, \mathrm{Zn}$ and $\mathrm{Mn}$ content but EC, N and Cu content were greater than DP with (8) number of leaves. Potting media containing SD and CC in combination with coconut coir, had better plant height. Because the wellness of plant parts (leaves, roots, trunks) depends on the availability of essential nutrients like nitrogen to enhance the plant's biological processes. Control (CNC) media has $2.16 \mathrm{mg} \mathrm{kg}^{-1} \mathrm{Zn}$ content but the normal range for zinc in the growing medium is 0.10 $2.0 \mathrm{mg} \mathrm{kg}^{-1}$. Zinc is essential in the formation of auxins, which help for growth regulation and stem elongation (Ed Bloodnick 2018). Potting media containing sawdust and corn cobs singly but date palm in combination with coconut coir had the lowest leaf area and plant growth. Leaf area with CNC was greater than all other potting media due to higher level of nitrogen content. Nitrogen plays a vital role in photosynthesis (Tajer 2016). Best potting media were rice hulls and corn cobs in combination with coconut coir for growth and fresh plant shoot weight. Chemical properties of media showed that maximum nutrient contents like $\mathrm{P}(0.31 \%), \mathrm{K}$ (3.05\%), Mn (9.04 $\left.\mathrm{mg} \mathrm{kg}^{-1}\right), \mathrm{Zn}\left(2.71 \mathrm{mg} \mathrm{kg}^{-1}\right)$ and $\mathrm{Cu}(3.26 \mathrm{mg} \mathrm{kg}-$ 1) were present in $\mathrm{CNC}+\mathrm{RH}$. Phosphorus plays a key role in photosynthesis, protein synthesis, storage and transfer of energy and respiration. Similarly, potassium is an enzyme activator for plant growth (Tajer 2016). Hence, presence of high content of phosphorus and potassium may be the reason behind higher shoot weight with CNC+RH media.

Almost all the potting media played same role in fresh plant root weight as well as fresh plant shoot weight. The $\mathrm{CNC}+\mathrm{RH}$ had the highest nutrient contents so it performed better than all other potting media. Manganese content of this media was also highest than all other potting media due to which various biological systems including photosynthesis, respiration, and nitrogen assimilation 
were better, and manganese is also involved in root cell elongation and resistance to root pathogens (Ed Bloodnick 2018).

Potting media containing rice hulls and corn cobs with combination of coconut coir were more suitable for plant growth and dry plant shoot weight. Control (CNC) was also good for dry plant shoot weight. Control had maximum plant height and leaf area index with good oven dry shoot weight. But $\mathrm{CNC}+\mathrm{RH}$ had maximum nutrient contents with maximum oven dry shoot weight. According to Aklibasinda., et al. [21] rice hulls with peat in 10:90 gave maximum dry shoot weight of Scotch pine. From above all physical parameters of plants, potting media containing $\mathrm{CNC}+\mathrm{RH}$ and $\mathrm{CNC}+\mathrm{CC}$ were the best potting media for plant growth and yield, respectively as compared to others. Scotch pine (Pinus sylvestris) had maximum dry root weight in a potting media containing rice hulls 10:90 peat [21].

Potassium in potting media containing $(\mathrm{CNC}+\mathrm{RH})$ was at the highest but plants grown in this media had the lowest potassium content. It may be due to dilution effect of potassium in well grown plants with this medium. But date palm coir and rice hulls as the only medium gave better potassium contents in plants. Potting media containing $\mathrm{CNC}+\mathrm{CC}$ had lower manganese content but plants of this media had the highest manganese content than all other media. Potting media containing $\mathrm{CNC}+\mathrm{RH}$ had the highest manganese content but in plants it was low as with other potting media. But rice hulls gave higher manganese contents in plant as sole medium in potting media. Zinc was also highest in potting media containing $\mathrm{CNC}+\mathrm{RH}$ followed by $\mathrm{CC}$, but plants in the same potting media contained very low zinc content than control and other potting media. Potting medium containing $\mathrm{CNC}+\mathrm{RH}$ had more copper content but plants of potting media containing only $\mathrm{RH}$ had higher copper content. Potting media SD contained higher copper but plants of CNC+SD had less copper content [22-28].

\section{Conclusion}

On the basis of plant physical parameters, it was concluded that the best potting mixes in combination were rice hulls + coconut coir and corn cobs + coconut coir, respectively. These potting mixes could be used as alternative for coconut coir in potting mix. Rice hulls and date palm coir could be used as a sole alternative of coconut coir in potting mix. Potting mix containing coconut coir had maximum nitrogen content, which caused greater leaf area of plants. From chemical analysis, $\mathrm{pH}$ of all potting mixes was almost neutral. Potting mix containing rice hulls + coconut coir had the highest phosphorus, potassium, zinc, manganese and copper content compared to rest of the substrates. Over all, nutrient contents of potting mixes had non-significant difference. The local waste materials like rice hulls, date palm coir and corn cobs should be further evaluated as alternative of coconut coir in potting mix.

\section{Conflict of Interest}

Declare if any financial interest or any conflict of interest exists.

\section{Bibliography}

1. Savvas D. "Nutrient solution recycling in hydroponics". In: Hydroponic Production of Vegetables and Ornamentals (Savvas D; Passam H C, eds), Embryo Publications, Athens, Greece. (2002): 299-343.

2. Raviv M et al. "Significance of soilless culture in agriculture". Soilless Culture Theory and Practice. Elsevier, Amsterdam (2008): 1-11.

3. Nejad A., Ismaili A. "Changes in growth, essential oil yield and composition of geranium (Pelargonium graveolens L.) as affected by growing media". Journal of the Science of Food and Agriculture 94.5 (2014): 905-910.

4. Schmilewski G. "Growing medium constituents used in the EU". In International Symposium on Growing Media 819. (2007): 33-46.

5. Olaria M., et al. "Effect of different substrates for organic agriculture in seedling development of traditional species of Solanaceae". Spanish Journal of Agricultural Research 14.1 (2016).

6. Olle M., et al. "Vegetable quality and productivity as influenced by growing medium: a review". Agriculture 99.4 (2012): 399408.

7. Bhat NR., et al. "Growing substrates for organic lettuce production in Kuwait". World Journal of Agricultural Sciences 9.2 (2013): 143-147

8. Tzortzakis NG and Economakis CD. "Impacts of the substrate medium on tomato yield and fruit quality in soilless cultivation". Horticultural Sciences 35.2 (2008): 83-89.

9. Apo-daca LE. "Peat, US Department of the Interior, Reston, Virginia”. (2013): 1-8.

10. Jackson ML. “Soil Chemical Analysis". Prentice Hall, Inc., Englewood cliffs, New Jersy. (1973).

11. Benito M., et al. "Chemical and microbiological parameters for the characterization of the stability and maturity of pruning waste compost". Biology and Fertility of Soils 37.3 (2003): 184189.

12. Shapter R. "The estimation of phosphorus in plant material". Journal and Proceedings, Australian Chemical Institute 7 (1940): 155-163.

13. Wright RJ and Stuczynski T. "Atomic absorption and flame emission spectrometry". Methods of Soil Analysis Part 3-Chemical Methods (1996): 65-90.

14. Lindsay WL and Norvell WA. "Development of a DTPA soil test for zinc, iron, manganese, and copper". Soil Science Society of America Journal 42.3 (1978): 421-428. 
15. Steel R. "Analysis of variance I: The one-way classification". Principles and procedures of statistics A biometrical approach, 2nd Ed (1997): 139-203.

16. Bunt AC. "Media and mixes for container-grown plants. A manual on the preparation and use of growing media for pot plants (2nd Ed.)" Unwin Hyman Ltd, London, UK (1988): 307.

17. Pennisi BV and Thomas PA. "Essential pH management in greenhouse crops". Bulletin 1256. Issued in furtherance of cooperative Extension work, Acts of May 8 and June 30, 1914, The University of Georgia College of Agricultural and Environmental Sciences and the U.S Department of Agriculture Cooperating (2005).

18. Ngamau K. "Evaluation of Macadamia shells as a component of pot plant media in Spathiphyllum". Proceedings of the fourth workshop on Sustainable Horticultural Production in the tropics. Dept. of Horticulture, Moi University, Eldoret, Kenya (2004).

19. Magat S. S., et al. "Mid-term yield response (1996-2001) of coconut to the application of coconut coir dust or coco peat in coastal area (Mindanao, Philippines)" (2002).

20. Ingram DL. "Understanding soilless media test results and their implications on nursery and greenhouse crop management" (2014).

21. Aklibasinda M., et al. "Effects of different growing media on Scotch pine (Pinus sylvestris) production". Journal of Animal and Plant Sciences 21.3 (2011): 535-541.

22. Atiyeh RM., et al. "Effects of vermicomposts and composts on plant growth in horticultural container media and soil". Pedobiologia 44.5 (2000): 579-590.

23. Carlile WR., et al. "Organic growing media: Constituents and properties”. Vadose Zone Journal 14.6 (2015).

24. Garcia-Gomez A., et al. "Growth of ornamental plants in two composts prepared from agroindustrial wastes". Bioresource Technology 83.2 (2002): 81-87.

25. Grafiadellis I., et al. "An economic analysis of soilless culture in gerbera production". Horticultural Science 35.2 (2000): 300303.

26. Nair A., et al. "Alfalfa-based organic amendment in peat-compost growing medium for organic tomato transplant production". Horticultural Sciences 46.2 (2011): 253-259.

27. Van OE., et al. "Technical equipment in soilless production systems. Soilless Culture: Theory and Practice". Elsevier, Amsterdam. (2008): 157-207.
28. Vaughn SF., et al. "Extracted sweet corn tassels as a renewable alternative to peat in greenhouse substrates". Industrial Crops Products 33.2 (2011): 514-517.

\section{Volume 3 Issue 11 November 2019}

(c) All rights are reserved by Afshan., et al. 